\title{
Influence of Moderate Smoking on Physical Fitness and Local Muscle Oxygenation Profile during Incremental Exercise
}

\author{
Yoshiko Kimura', Yohko Nakamoto', Hideo Shitama', Saburo Ohmine', \\ Makoto IDE ${ }^{2}$ and Kenji HACHISUKA ${ }^{3}$ \\ ${ }^{\prime}$ Department of Rehabilitation Medicine, University Hospital of Occupational and Environmental \\ Health, Japan. Yahatanishi-ku, Kitakyushu 807-8555, Japan \\ ${ }^{2}$ Saint Mary's Hospital, Rehabilitation Center, Japan. Tsubukuhonmachi, Kurume 830-8543, Japan \\ ${ }^{3}$ Department of Rehabilitation Medicine, School of Medicine, University of Occupational and \\ Environmental Health, Japan. Yahatanishi-ku, Kitakyushu 807-8555, Japan
}

Abstract: To reveal the influence of chronic moderate smoking on physical fitness and local muscle oxygenation profile, we compared the oxygen uptake $\left(\dot{\mathrm{VO}}_{2}\right)$, $\mathrm{CO}_{2}$ output, respiratory rate, minute ventilation and blood lactate accumulation between six moderate smokers and ten non-smokers during incremental exercise. In order to know the difference of the peripheral oxygen supply to the muscles between the two groups, oxygenation profiles based on the changes of oxygenated hemoglobin $\left(\mathrm{O}_{2} \mathrm{Hb}\right)$ in the right vastus lateralis muscles were observed using near-infrared spectroscopy (NIRS). The intensity of incremental exercise using a bicycle ergometer was from $10 \mathrm{~W}$ to $80 \%$ of the maximum heart rate $\left(80 \% \mathrm{HR}_{\max }\right)$ of each subject. There were no significant differences between the two groups in $\dot{\mathrm{VO}}_{2}$ and work rate at the level of $2 \mathrm{mmol} / \ell$ lactate or $80 \% \mathrm{HR}$ $\max _{\max }(P<0.05)$. However, as to the local muscle oxygenation profile during exercise, 5 out of the 6 smokers showed a decrease of $\mathrm{O}_{2} \mathrm{Hb}$ throughout the incremental exercise, but 8 out of the 10 non-smokers showed a gradual increase of $\mathrm{O}_{2} \mathrm{Hb}$ throughout the exercise. In conclusion, our results suggest that chronic moderate smoking might cause a change of local muscle oxygenation profile during incremental exercise, even if the smokers have shown no decrease in physical fitness.

Key words: near-infrared spectroscopy, smoking, physical fitness, oxygenated hemoglobin. (Received 23 February 2007, accepted 18 April 2007) 


\section{Introduction}

The negative effects of cigarette smoking on health are well known, and the population attributable fraction between smoking habit and death from all causes, which is an index of death prevention in the community when habitual smokers abstain from cigarette smoking, is $9.0 \%$ for males and $1.6 \%$ for females, according to NIPPON DATA 80 [1] .

Cigarette smoking also affects exercise performance. Maksud et al. [2] reported that the mean minute ventilation and perceived exertion were higher in cigarette smokers than in non-smokers, but that aerobic power and the physical work capacity did not differ. Huerta et al. [3] found that smoking was associated with lower $\dot{\mathrm{VO}}_{2 \max }$ in $18-25$ years-old persons who had been discharged from military service in the Israeli Defense Forces. Sidney et al. [4] revealed that the mean exercise duration in smokers was shorter than that in nonsmokers, but the mean time to a heart rate of 130 beats $/$ min was increased. Decreased $\mathrm{O}_{2}$ delivery to the working muscles due to increased carboxyhemoglobin $(\mathrm{COHb})$ caused a significant reduction in $\dot{\mathrm{V}}_{2 \max }$ and in the anaerobic threshold(AT) in smokers [5]. At the $11 \% \mathrm{COHb}$ level (typical of a heavy cigarette smoker), exercise duration, $\dot{\mathrm{V}} \mathrm{O}_{2 \max }$ and $\mathrm{AT}$ were $645 \pm 24 \mathrm{~s}, 45.5 \pm 3.5 \mathrm{ml} / \mathrm{kg} \cdot \min$ and $28.3 \pm 2.7 \mathrm{ml} / \mathrm{kg} \cdot \min$, respectively, whereas, at the $20 \% \mathrm{COHb}$ level, exercise duration, $\dot{\mathrm{VO}}_{2 \max }$ and AT were $599 \pm 20 \mathrm{~s}, 41.4 \pm 2.9 \mathrm{ml} / \mathrm{kg} \cdot \min$ and $25.2 \pm 1.9 \mathrm{ml} / \mathrm{kg} \cdot \mathrm{min}$, respectively.

It remains unclear, however, whether the physical work capacity of moderate smokers is lower than that of non-smokers, and whether muscle oxygenation in moderate smokers is lower during submaximal exercise. In this study, we planned to assess the contribution of muscle oxygenation to the aerobic exercise tolerance of moderate smokers using nearinfrared spectroscopy (NIRS). The NIRS is a non-invasive and continuous method to determine oxygenation and hemodynamics in tissue. Regarding its reliability and validity, NIRS proved to be an appropriate tool to provide information about local muscle $\mathrm{O}_{2}$ consumption and local blood flow [6].

\section{Methods}

The subjects were 16 middle-aged office workers in our university hospital, who voluntarily answered an advertisement displayed on posters seeking study subjects. The inclusion criteria for the subjects in this study were the following: 1) each subject had to be male, 2-a) he had to be smoking from 10-20 cigarettes a day over the last 10 years, smoker group, or 2 -b) he had to be a complete non-smoker for the last 10 years, non-smoker group, 3) he had to be aged between 40 and 55 years old, 4) he must never have had abnormal findings at his annual regular medical check-up, which included a physical examination, a biochemical blood test, urinalysis, electrocardiography and a chest X-ray, 5) he must not be participating regularly in sports activities, and 6) he must give informed consent as regards the purpose and procedure of the experiment. According to the inclusion criteria, 16 out of 19 applicants were taken on as subjects: 6 were approved as smoker group subjects, and 10 as non-smoker group subjects. 
Height and body weight were measured before the experiment, and the body mass index $\left(\mathrm{kg} / \mathrm{m}^{2}\right)$ of each subject was calculated based on the formula: body weight $(\mathrm{kg}) / \mathrm{height}(\mathrm{m})$ $x$ height $(\mathrm{m})$. Total serum cholesterol was obtained from the data of the last annual regular medical check-up. The subjects were interviewed about smoking and physical activity before the experiment, and their approximate amounts of smoking and daily physical activity were expressed using both the Brinkman index[7] and the short questionnaire for the habitual physical activity index (HPAI)[8], respectively. The Brinkman index is a simple scale, defined as the average number of cigarettes smoked per day multiplied by the number of years of smoking. The HPAI is a self-administered scale to assess physical activity at work, sports during leisure time, and physical activity during leisure time excluding sport, and its construct validity and test-retest reliability have been established. It consists of 16 items, and each item is rated from 1 to 5 . Based on the formula, these scores are calculated and are added together, to give the work, sport and leisure-time indexes. The total HPAI score is obtained by adding the three indexes, which gives a result within a range between 3 (sedentary) and 15 (active) for each subject.

Before the experiment, which was carried out at least 2 hrs after lunch in both groups, the smokers were ordered to abstain from smoking for at least 5 hrs. A subject sat on an electrically braked bicycle ergometer (Isopower TKK 1251, Takei Scientific Inc., Niigata, Japan), and its saddle height was adjusted to obtain a slightly flexed knee position when the pedal was at the bottom position. After a 4-min rest period, each subject was asked to pedal the bicycle ergometer (at $10 \mathrm{~W}$ resistance) at a rate of $60 \mathrm{rpm}$, and another $10 \mathrm{~W}$ resistance was added every minute up to $80 \%$ of the maximal heart rate $\left(80 \% \mathrm{HR}_{\max }\right)$. Pulmonary ventilation ( $\dot{\mathrm{V}}_{\mathrm{E}}$, in BTPS), $\mathrm{O}_{2}$ uptake $\left(\dot{\mathrm{VO}}_{2}\right.$, in STPD), $\mathrm{CO}_{2}$ output $\left(\dot{\mathrm{VCO}}_{2}\right.$, in STPD) and respiratory rate $(\mathrm{RR})$ were measured breath-by-breath using a Westron Mass Spectrometer (WSMR-1400A, Arcosystem Inc., Chiba, Japan). Heart rate was also monitored using an electrocardiogram (Bioview1000, NEC, Tochigi Japan). Tidal volume $\left(\mathrm{V}_{\mathrm{T}}\right)$, ventilatory equivalent for oxygen $\left(\dot{\mathrm{V}}_{\mathrm{E}} / \dot{\mathrm{VO}}_{2}\right)$ and oxygen pulse $\left(\mathrm{O}_{2}\right.$ pulse), reflecting the $\mathrm{O}_{2}$ extracted from the blood delivered to the tissues by each heart beat[9], were calculated from these measurements. At rest and during the last $45-60 \mathrm{~s}$ of every workload, a sample of forearm venous blood was taken through a catheter fixed in the right median forearm vein, and the blood lactate concentration was determined enzymatically. $\mathrm{VO}_{2}$ at $2 \mathrm{mmol} / \ell$ lactate accumulation in the blood was detected using the $\mathrm{V}$-slope method, and $2 \mathrm{mmol} / \ell$ lactate accumulation, which is conventionally employed to determine the lactate threshold[10], was compared between the smoker and non-smoker groups.

NIRS (OM 200, Shimadzu Co., Kyoto, Japan) was used to monitor continuous muscle (or, more precisely, capillary-venular) oxygenation changes. The probe was fixed by a Velcro strap and biadhesive tape at the lower one-third of the right vastus lateralis muscle parallel to the major axis of the right thigh. The sampling frequency was set at $1 \mathrm{~Hz}$.

NIRS is used to evaluate the changes in muscle oxygenation profile, that is to say, if blood supply to peripheral muscles is enough or more during exercise, $\mathrm{O}_{2} \mathrm{Hb}$ remains at a constant level (type 2), or continues to increase (type 1), once it decreases immediately at the onset of incremental exercise. If blood supply is not enough, $\mathrm{O}_{2} \mathrm{Hb}$ continues to decline throughout the 
exercise (type 3).

The ankle-brachial systolic pressure index (ABPI) at rest was measured before the experiment, using PWV/ABI VP1000 (Colin, Aichi, Japan). ABPI is an index of blood flow in the lower extremities, and a value below 0.9 is considered as abnormal.

All the subjects were thoroughly informed about the purpose of the experiment and its practical details before they gave their written consent to participate. This experiment was approved by the Ethics Committee of the University of Occupational and Environmental Health.

\section{Data analysis}

Results were presented as the means \pm standard deviation. Differences in ABPI, HPAI, $\dot{\mathrm{V}}_{\mathrm{E}}, \mathrm{RR}, \mathrm{V}, \dot{\mathrm{V}} \mathrm{E} / \dot{\mathrm{VO}}_{2}$ and $\mathrm{O}_{2}$ pulse between the smoker and non-smoker groups were analyzed by unpaired Student's $t$ test. Because the predicted values of 5 cells of muscle oxygenation profiles were less than 5 , the differences in muscle oxygenation profiles between the smoker and non-smoker groups were determined by Fisher's exact test, after cells classified as being of the type 2 and type 3 were combined together. A probability of $P<0.05$ was considered statistically significant.

\section{Results}

There were no significant differences in age, height, body mass index, total serum cholesterol and ankle-brachial systolic pressure between the smoker and non-smoker groups (Table 1: $P>0.05)$. The smoker group smoked 15-20 cigarettes a day for more than 20 years, and its Brinkman index $(446.5 \pm 122.6)$ was significantly different from that of the non-smoker group $(P<0.05)$. The non-smoker group had never smoked at all, except one subject, who had smoked 10 cigarettes a day 15 years ago for less than one year. No significant differences in physical activities at work, home and during leisure time were found between the smoker and non-smoker groups $(P<0.05)$.

At rest time of the incremental ergometric exercise, no significant differences in the heart rate and $\dot{\mathrm{VO}}_{2}$ were found between the smoker and non-smoker groups (Table 2: $P<0.05$ ). At $80 \% \mathrm{HR}_{\max }$ and $2 \mathrm{mmol} / \ell$ lactate accumulation, there were no significant differences in heart rate, $\dot{\mathrm{VO}}_{2}$, work rate and rating of perceived exertion (RPE) between the smoker and nonsmoker groups $(P<0.05)$.

Respiratory responses during incremental exercise were plotted against work rate. $\dot{V E}$ (Fig. 1A) showed no significant difference between the groups except at rest time. RR (Fig. 1B) was slightly higher in the smoker group, and a significant difference was found only at 10,70 and $80 \mathrm{~W}$. There was no significant difference in $\mathrm{V}_{\mathrm{T}}(\mathrm{Fig} .1 \mathrm{C})$ between the two groups. The ventilatory equivalent for oxygen in the smoker group (Fig. 1D) was significantly higher at from 10 to $70 \mathrm{~W}$. There was no significant difference in $\mathrm{O}_{2}$ pulse between the two groups.

NIRS revealed that 1 of the smoker group had a type 2 muscle oxygenation profile during the incremental exercise, and 5 of the smoking group had a type 3, whereas 8 of the nonsmoker group had a type 1, 1 had a type 2 and 1 had a type 3 profile (Fig. 2). More of the 
smoker group had a type 2 or a type 3 muscle oxygenation profile than the non-smoker group (Fisher's exact test, $P<0.05$ ).

Table 1. Comparison of general characteristics between smoker and non-smoker group

\begin{tabular}{|c|c|c|c|}
\hline & $\begin{array}{l}\text { Smoker group } \\
\qquad(\mathrm{N}=6)\end{array}$ & $\begin{array}{l}\text { Non-smoker group } \\
\qquad(\mathrm{N}=10)\end{array}$ & $P$-value \\
\hline Age (years old) & $50.3 \pm 4.0$ & $48.7 \pm 4.4$ & \\
\hline Height $(\mathrm{cm})$ & $169.0 \pm$ & $167.9 \pm 7.2$ & \\
\hline Weight (kg) & $65.7 \pm 6.3$ & $69.9 \pm 6.9$ & \\
\hline Body mass index $\left(\mathrm{kg} / \mathrm{m}^{2}\right)$ & $23.0 \pm 2.2$ & $24.8 \pm 2.6$ & \\
\hline Total cholesterol (mg/dl) & $215.0 \pm 14.0$ & $204.1 \pm 26.2$ & \\
\hline Ankle-brachial systolic pressure index & $1.03 \pm 0.15$ & $1.19 \pm 0.13$ & \\
\hline Brinkman index & $446.5 \pm 122.6$ & $0.8 \pm 1.8$ & $P<0.05$ \\
\hline Habitual physical activity index & $8.1 \pm 0.8$ & $7.8 \pm 1.1$ & \\
\hline
\end{tabular}
means \pm SD

Brinkman index: the average number of cigarettes smoked per day multiplied by the number of years of smoking, Habitual physical activity index: the total score falls between 3 (sedentary) and 15 (active)

Table 2. Comparison of physical measurements between smoker and nonsmoker group

\begin{tabular}{|c|c|c|}
\hline & $\begin{array}{l}\text { Smoker group } \\
\qquad(\mathrm{N}=6)\end{array}$ & $\begin{array}{l}\text { Non-smoker group } \\
\qquad(\mathrm{N}=10)\end{array}$ \\
\hline \multicolumn{3}{|l|}{ At rest } \\
\hline Heart rate (beats/min) & $80.2 \pm 11.7$ & $74.8 \pm 9.1$ \\
\hline$\dot{\mathrm{VO}}_{2}(\mathrm{ml} / \mathrm{kg} \cdot \min )$ & $4.2 \pm 0.7$ & $3.8 \pm 0.7$ \\
\hline \multicolumn{3}{|l|}{ At $80 \% \mathrm{HR}_{\max }$} \\
\hline Heart rate & $136.0 \pm 3.3$ & $137.1 \pm 3.6$ \\
\hline$\dot{\mathrm{VO}}_{2}$ & $17.4 \pm 2.5$ & $18.0 \pm 2.4$ \\
\hline Work rate $(\mathrm{W})$ & $100.0 \pm 8.3$ & $111.0 \pm 20.8$ \\
\hline RPE (Borg scale) & $14.7 \pm 2.4$ & $14.2 \pm 2.4$ \\
\hline \multicolumn{3}{|c|}{ At $2 \mathrm{mmol} / \ell$ lactate accumulation } \\
\hline Heart rate & $122.8 \pm 8.8$ & $128.6 \pm 11.4$ \\
\hline$\dot{\mathrm{VO}}_{2}$ & $15.9 \pm 2.6$ & $16.6 \pm 2.1$ \\
\hline Work rate & $81.7 \pm 23.4$ & $96.0 \pm 21.2$ \\
\hline
\end{tabular}


$1 \mathrm{~A}$

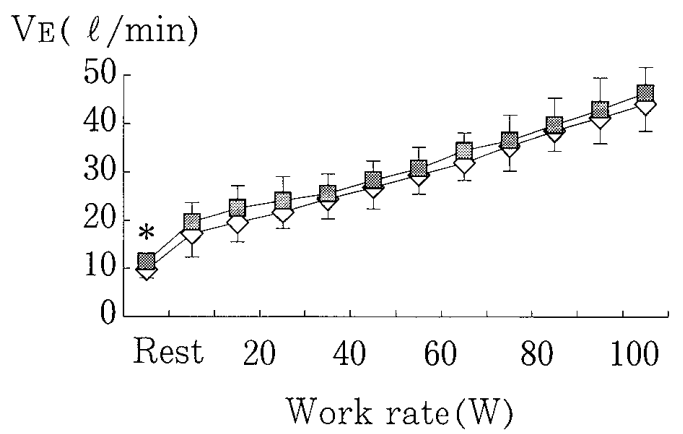

$1 \mathrm{~B}$

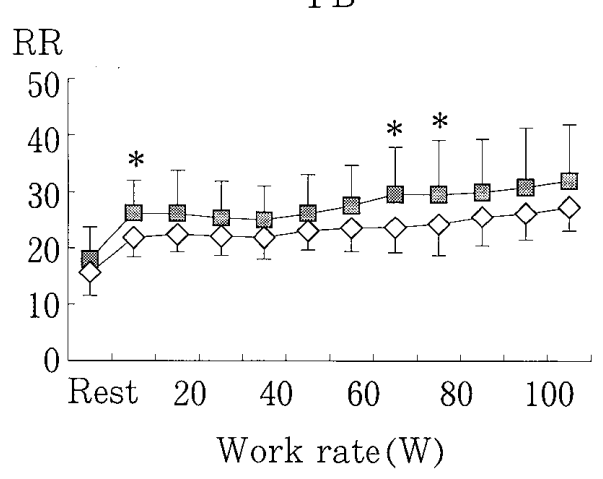

$1 \mathrm{C}$

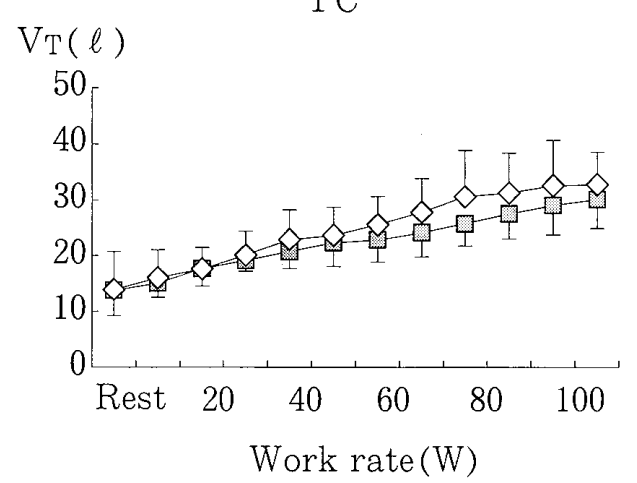

$1 \mathrm{D}$

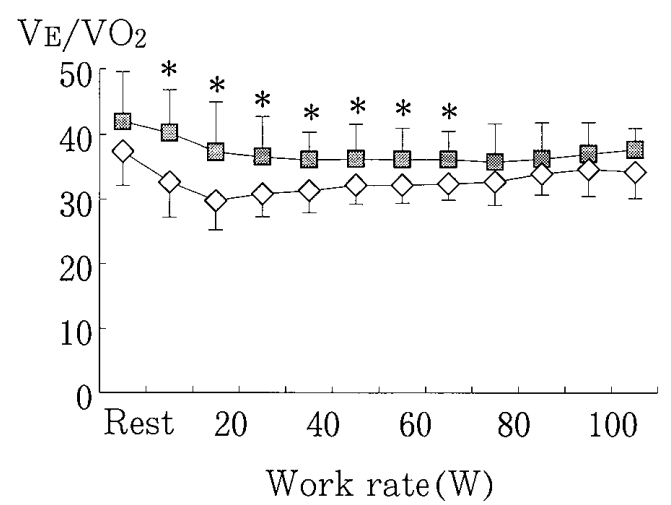

Fig. 1. Pulmonary responses during incremental exercise.

Because maximum intensity of the incremental exercise was $80 \% \mathrm{HR}_{\max }$, each final work rate was different, and the values up to $110 \mathrm{~W}$ are shown in the figures.

1A: $\mathrm{V}_{\mathrm{E}}(\ell / \mathrm{min}), 1 \mathrm{~B}: \mathrm{RR}$ (breaths $\left./ \mathrm{min}\right), 1 \mathrm{C}: \mathrm{V}_{\mathrm{T}}(\ell), 1 \mathrm{D}: \mathrm{V}_{\mathrm{E}} / \mathrm{VO}_{2}, *: P<0.05$, $\diamond$ : non-smokers, $\square$ :smokers.

\section{Discussion}

The main finding of this study was that the muscle oxygenation profile obtained with NIRS showed a significant difference between the smoker and non-smoker groups, although there were no significant differences in heart rates, $\mathrm{VO}_{2}$, work rate, RPE at the levels of 2 mmol/ $\ell$ lactate accumulation in blood nor $80 \% \mathrm{HR}_{\max }$. The subjects in this study were appropriately selected from applicants based on the inclusion criteria, and the subjects'profiles, including their physical characteristics and activity level, indicate that they were average middle-aged sedentary office workers without any disease. The smoker group, whose Brinkman index was $446.5 \pm 122.6$, is regarded as moderate smokers[11], and they seem to have no change in small airway dysfunction or emphysematous destruction of lung parenchyma according to the annual regular medical check-up. However, we should be wary about extrapolating the results of this study to all smokers, because this study has limitations, i.e. the number of subjects is small, and we did not monitor venous carboxyhemoglobin. 


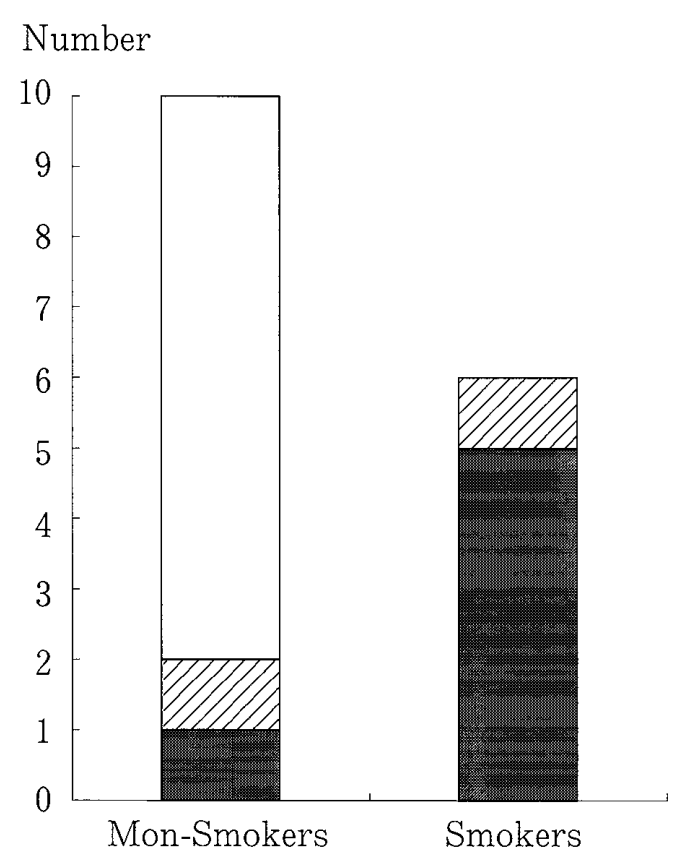

Fig. 2. NIRS profiles during incremental exercise. NIRS profiles were classified into three types: in type $1, \mathrm{O}_{2} \mathrm{Hb}$ dropped immediately after the onset of the exercise and gradually increased until the end of the exercise; in type $2, \mathrm{O}_{2} \mathrm{Hb}$ was stable, once it dropped immediately after the onset of the exercise; and in type $3, \mathrm{O}_{2} \mathrm{Hb}$ continued to decline throughout the incremental exercise. Eight out of 10 non-smokers had a type 1 profile, but none of the smokers had a type 1 profile. Five out of 6 smokers belonged to a type 3 , but only 1 of the smokers had a type 2 profile.

$\square$ :type 1, 政:type 2, :type $3,-$ : oxygenated $\left(\mathrm{O}_{2} \mathrm{Hb}\right)$, - : deoxygenated $\mathrm{Hb}$. $\triangle \mathrm{Hb}$

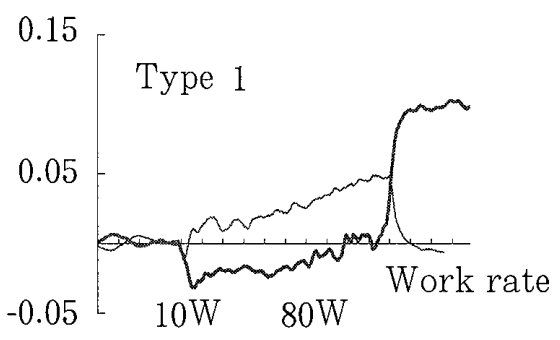

$\triangle \mathrm{Hb}$

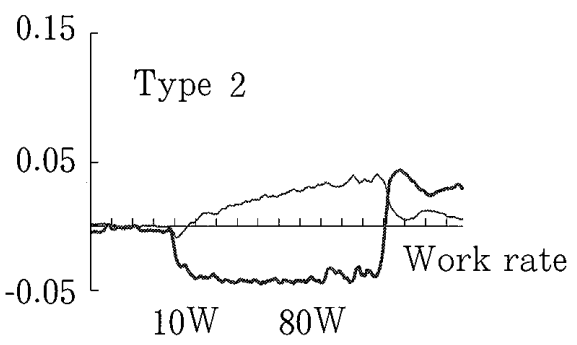

$\triangle \mathrm{Hb}$

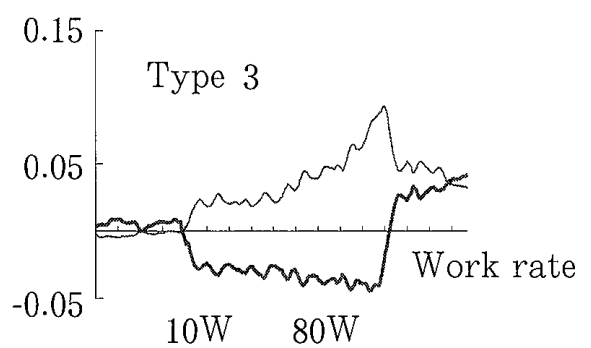

NIRS has been used to evaluate the changes in muscle oxygenation during exercise noninvasively and continuously. Muscle oxygenation measured with NIRS indicates capillary and venular $\mathrm{O}_{2} \mathrm{Hb}$ saturation around the muscle and $\mathrm{O}_{2} \mathrm{Mb}$ saturation in tissues, but approximately $75 \%$ of the total tissue optical signal during exercise arises from $\mathrm{O}_{2} \mathrm{Hb}$, with the remainder associated with tissue $\mathrm{O}_{2} \mathrm{Mb}$. Therefore, the change in $\mathrm{O}_{2} \mathrm{Hb}$ and deoxygenated hemoglobin $(\mathrm{HHb})$ is related to the balance of blood flow in the local muscle and $\mathrm{O}_{2}$ extraction by the exercising muscle.

During low intensity exercise, the influence of increased blood flow on activated muscles is greater than that of $\mathrm{O}_{2}$ extraction [12]. In the present study, $\mathrm{O}_{2} \mathrm{Hb}$ decreased immediately at the onset of the incremental exercise and continued to decrease gradually during exercise (type 3) in 1 out of the 10 non-smokers and in 5 out of the 6 smokers. This fact may mean that chronic moderate smoking gives rise to changes in the muscle oxygenation profile, even 
if the smoker has no decrease in physical fitness. $\mathrm{O}_{2}$ kinetics similar to those of the smokers is also found in patients with arteriosclerosis obliterans (Ohmine, unpublished data), that is, $\mathrm{O}_{2} \mathrm{Hb}$ in the calf muscle measured with NIRS began to decrease immediately after the beginning of exercise on a treadmill, and continued to decrease to the end of the exercise. In ASO patients, blood flow to the exercising muscle is disturbed due to peripheral vascular dysfunction [13].

$\dot{\mathrm{VO}}_{2}$ at $2 \mathrm{mmol} / \ell$ lactate accumulation and work rates at $80 \% \mathrm{HR}_{\max }$ were the same in the smoker and non-smoker groups in the present study. Cooper et al. [14] evaluated a 12-min endurance run for distance in smokers and non-smokers, where smokers showed a reduced performance compared to non-smokers. They reported that in the smoker group, endurance was negatively proportional to the number of cigarettes per day and the duration of smoking. So, the difference between our results and theirs may be due to the number of cigarettes smoked per day or the smoking history.

Krumholz et al. [15] studied the factors influencing work capacity in middle-aged, longterm smokers, and found that the pulmonary diffusing capacity and the diffusing capacity/ total lung capacity ratio were significantly lower in smokers. Impaired diffusion capacity with a fixed amount of oxygen would require a larger $\dot{V}_{\mathrm{E}}[2]$. In our data, there was no difference in the $\dot{\mathrm{V}}_{\mathrm{E}}$ between the smoker and non-smoker groups, however, the $\dot{\mathrm{V}}_{\mathrm{E}} / \mathrm{O}_{2}$ ratio was significantly higher in the smoker group for up to $70 \mathrm{~W}$. Chronic moderate smoking may have caused a subtle change in the pulmonary diffusing capacity.

In the present study, we didn't examine the level of blood CO. CO is known to displace $\mathrm{O}_{2}$ from hemoglobin and to reduce the $\mathrm{O}_{2}$ carrying capacity of blood [16]. Gowa et al. [17] studied the effect of stopping smoking for 4 weeks using five well-trained habitual smokers, and found that the ventilation threshold $\left(\mathrm{V}_{\mathrm{T}}\right)$ elevated significantly after only 2 weeks of stopping smoking. They attributed the result to lowered $\mathrm{COHb}$ and $\mathrm{COMb}$ densities due to stopping smoking, since the $\mathrm{O}_{2}$ pulse increased remarkably, which means that the $\mathrm{O}_{2}$ supply to the exercising muscles was improved. Koike et al. [5] reported that $20 \% \mathrm{COHb}$ decreased exercise duration, $\dot{\mathrm{V}}_{2 \max }$ and AT more than $11 \% \mathrm{COHb}$. Horvath et al. [18] studied the precise level of $\mathrm{COHb}$ at which $\dot{\mathrm{VO}}_{2 \max }$ was impaired and found that $\dot{\mathrm{V}} \mathrm{O}_{2 \max }$ was not significantly decreased until $\mathrm{COHb}$ levels reached $4.3 \%$. In our data, $\dot{\mathrm{VO}}_{2}$ at $2 \mathrm{mmol} / \ell$ lactate accumulation and $80 \% \mathrm{HR}_{\max }$ was the same in the smoker and non-smoker groups. Because our smokers were moderate smokers [11], this might have had less of an affect on their $\mathrm{O}_{2}$ carrying capacity due to the low rate of $\mathrm{COHb}$.

In conclusion, the chronic moderate smokers in this study had the same aerobic exercise performance as the non-smokers. NIRS could detect subtle changes in local muscle oxygenation of the chronic moderate smokers even if smoking did not diminish physical fitness. The precise pathophysiology of the disturbance of local muscle oxygenation in the chronic moderate smokers still remains unclear, but the pulmonary diffusing capacity and local circulation in muscles may have an influence on this phenomenon. Further study is needed to focus on the pathophysiology of this physical response of chronic moderate smokers during exercise. 


\section{Acknowledgement}

We thank Dr. Futoshi Wada (Department of Rehabilitation Medicine, School of Medicine, University of Occupational and Environmental Health, Japan), for his assistance with the study design and data analysis.

\section{References}

1. Kawaminami T, Minowa M, Okayama A, Hayakawa T \& Ueshima H (2003): NIPPON DATA 80 Research Group. An association (population attributable fraction) between smoking habit and mortality from all causes, cancer and lung cancer: NIPPON DATA 80, 1980-1999. National integrated projects for prospective observation of non-communicable diseases and its trend in the aged. Jpn J Hyg 57: 669-673

2. Maksud MG \& Baron A (1980): Physiological responses to exercise in chronic cigarette and marijuana users. Eur J Appl Physiol 43: 127-134

3. Huerta M, Grotto I, Shemla S, Ashkenazi I, Shpilberg O \& Kark JD (2004): Ergometry estimation of physical fitness among Israeli soldiers. Mil Med 169: 217-220

4. Sidney S, Sternfeld B \& Gidding SS (1993): Cigarette smoking and submaximal exercise test duration in a biracial population of young adults: the CARDIA study. Med Sci Sports Exerc 25: $911-916$

5. Koike A \& Wasserman K (1992): Effects of acute reduction in oxygen transport on parameters of aerobic function during exercise. Ann Acad Med 21: 14-22

6. Beekvelt MC, Colier WN, Wevers RA \& Engelen GM (2001): Performance of near-infrared spectroscopy in measuring local $\mathrm{O}_{2}$ consumption and blood flow in skeletal muscle. J Appl Physiol 90: $511-519$

7. Brinkman GL \& Coates O (1963): The effect of bronchitis, smoking and occupation on ventilation. Ann Rev Respir Dis 87: 68-93

8. Baecke JA, Burema J \& Frijters JE (1982): A short questionnaire for the measurement of habitual physical activity in epidemiological studies. Am J Clin Nutr 36: 936-942

9. Grassi B, Quaresima V, Marconi C, Ferrari M \& Cerretelli P (1999): Blood lactate accumulation and muscle deoxygenation during incremental exercise. J Appl Physiol 87: 348-355

10. Hirsch GL, Sue DY, Wasserman K, Robinson TE \& Hansen JA (1985): Immediate effects of cigarette smoking on cardiorespiratory response to exercise. J Appl Physiol 58: 1975-1981

11. McDonough P \& Moffatt RJ (1999): Smoking-induced elevations in blood carboxyhaemoglobin levels: effect on maximal oxygen uptake. Sports Med 27: 275-283

12. Homma S, Fukuoka Y, Fuji N \& Eda H (1992): Study of human muscie circulation during bicycle exercise using near-infrared spectroscopy. Jpn J Phys Fitness Sports Med 41: 586-594

13. Komiyama T, Shigematsu H, Yasuhara H \& Muto T (2000): Near-infrared spectroscopy grades the severity of intermittent claudication in diabetics more accurately than ankle pressure measurement. Br J Surg 87: 459-466

14. Cooper KH, Gey GO \& Bottenberg RA (1968): Effects of cigarette smoking on endurance performance. J Am Med Assoc 203: 123-126

15. Krumholz RA \& Hedrick EC (1972): Exercise response of smoking and non-smoking middle-aged business executives. J Lab Clin Med 80: 79-87

16. Vogel JA \& Gleser MA (1972): Effect of carbon monoxide on oxygen transport during exercise. J Appl Physiol 32: 234-239

17. Gowa Y, Yoshioka T, Watanabe K \& Shiraishi T (1989): The effects of stop-smoking on aerobic 
capacity. Department of Health Science. Osaka Kyoiku University 38: 183-189

18. Horvath SM, Raven PB, Dahms TE \& Gray DJ (1975): Maximal aerobic capacity at different levels of carboxyhemoglobin. J Appl Physiol 38: 300-303

中等度の喫煙が体力や漸増運動時の局所筋の酸素動態におよぼす影響

木村 美子' ${ }^{1}$, 中元 洋子 ${ }^{1}$, 舌間 秀雄 ${ }^{1}$, 大峯 三郎 ${ }^{1}$, 井手 睦 ${ }^{2}$, 蜂須賀 研二 ${ }^{3}$

'産業医科大学病院 リハビリテーション部

2聖マリア病院 リハビリテーションセンター

${ }^{3}$ 産業医科大学医学部 リハビリテーション医学講座

要 旨：6 名の喫煙者と10 名の非喫煙者を対象として, 漸増運動が体力や未梢循環(酸素動態)にお よぼす影響について調べた.酸素動態の計測には近赤外線分光装置を用いて右外側広筋の 酸素化へモグロビン濃度 $\left(\mathrm{O}_{2} \mathrm{Hb}\right)$ の変化量を測定した. その結果 $80 \% \mathrm{HR}_{\max }$ 到達時や血中乳酸 濃度 $2 \mathrm{mmol} / \ell$ 時の仕事量, $\dot{\mathrm{V}} \mathrm{O}_{2} や \mathrm{HR} に$ に 2 群間で有意差はなかったが, 運動強度によっ てはRRや酸素当量が喫煙者において著明に高い傾向がみられた。 $\mathrm{O}_{2} \mathrm{Hb}$ 喫煙者の内5名で は運動の強度が上がるにつれて減少し続ける傾向がみられたが, 非契煙者では8名で運動中 を通じて増加し続けた、喫煙者では中等度の運動強度でも筋の酸素需要に供給が追いつい ていない可能性がある.喫煙者が運動を行う際には中等度の強度であっても末梢循環動態 に十分な配慮が必要であることが示唆された。

キーワード：近赤外線分光法, 喫煙, 体力, 酸素化へモグロビン.

J UOEH（産業医大誌）29（2）：149-158 (2007) 